\title{
Research on the Relationship among Board Management Cognition, Strategic Flexibility and Corporate Performance of Listed Companies in Media
}

\author{
Taiming Huang \\ Business Management, South China University of Technology, Guangdong, China \\ Email: 18620945926@163.com
}

How to cite this paper: Huang, T.M. (2018) Research on the Relationship among Board Management Cognition, Strategic Flexibility and Corporate Performance of Listed Companies in Media. American Journal of Industrial and Business Management, 8, 1327-1343.

https://doi.org/10.4236/ajibm.2018.85090

Received: April 25, 2018

Accepted: May 26, 2018

Published: May 29, 2018

Copyright $\odot 2018$ by author and Scientific Research Publishing Inc. This work is licensed under the Creative Commons Attribution International License (CC BY 4.0).

http://creativecommons.org/licenses/by/4.0/

\begin{abstract}
This paper first describes the definition of the concept of cognitive and flexible management strategy, summarizes the research literature on the relationship among knowledge management, flexible strategy and business performance, and proposed research model and hypotheses to this thesis, we selected 21 listed media companies in 2012-2016 a total of five years of data, and analysis to identify the variables of cognitive and flexible management strategy, namely to explore the cognitive and flexible management strategy, knowledge management and business performance; flexible strategy and corporate performance statistical analysis of the relationship among the way through the qualitative analysis, correlation analysis and regression analysis.
\end{abstract}

\section{Keywords}

The Media Industry, Knowledge Management, Flexible Strategy, Listed Companies

\section{Introduction}

\subsection{Research Background}

The management discussion and analysis report of the board of directors is an important part of the annual report of the listed company. Through management discussion and analysis, the investor can analyze and predict the description of the company's current business situation and future development in the report so as to determine whether to conduct investment in conclusion.

In the existing research, the use of relevant data software is usually used to ve- 
rify or predict the relationship between these aspects and the company's future performance development by analyzing management's perceptions of management companies and management's attitudes and strategies for the company's future development. Through these analyses, we can bring more industry-related information to investors as a supplementary knowledge of financial statements to make better investment decisions for investors.

The discussion and analysis of management are the embodiment of the management of the board of directors. The first part is the operation of the company during the reporting period: the status of the strategies and business plans for the previous year's report; if there are major changes in the financial status of the company, you need to make a detailed explanation of the reason for the change. In addition to the introduction of the company's internal strategy, it is possible to mention changes in the company's external environment, such as changes in the industry, the impact of changes in the macro environment on the industry and the company, the company's advantages, external threats, and the company's position in the industry competitive status, oligarch status, etc. In addition, if the company has a subsidiary or a company that participates in a large percentage of shares, it will provide relevant data.

The second part is the company's outlook for the business plan for the next reporting year. Whether the company's board of directors' management will make relevant strategic changes based on changes in the external environment or whether it will continue the current flexible strategy. The company may launch new businesses, major capital investment plans and financing plans to be carried out, and may also make appropriate predictions on the actual amount of production and operating status share of the next year.

According to the description of the background, the research object of this thesis is mainly listed on the media company. The specific research direction is the study of corporate management cognition, flexible strategy and corporate performance relationship. The main research content is roughly divided into three parts: First, management cognition and the study of corporate performance relations; the second part is the study of the relationship between management cognition and flexible strategy; the third part is the study of the relationship between flexible strategy and corporate performance.

\subsection{Research Significance and Innovation}

This dissertation mainly studies the relationship between management cognition, flexible strategy and corporate performance of listed companies in the media. By selecting the media industry and analyzing the existing data reports of the board of directors of the media listed companies, the relationship between corporate management cognition and corporate performance is explored, and the relationship between management cognition and flexible strategy, between flexible strategy and corporate performance. Relationship. Most of the listed companies in the media are at the transition point and are related to the building of socialist culture. Therefore, how to transform into a media company with a 
new era characterized by more integration with the Internet + is a non-negligible issue that all media listed companies have discussed together. Therefore, the research on this paper is more meaningful.

Text analysis is a common content in the computer field. Its main purpose is to use computers for information retrieval and data analysis. Because the opinions, emotions, evaluations, influences, opinions, emotions, and subjects in the text can often reflect the intention of the composer and the potential information expressed through texts, the application in management is only gradually started in recent years.

The innovation of this thesis is to apply the relationship between management cognition, flexible strategy and corporate performance to the media industry, use the data of listed companies, identify the management cognition and flexible strategy part of the board management discussion and analysis, and study the media. The relationship between corporate performance, management cognition and flexible strategy of listed companies. The ultimate goal of this paper is to hope that the listed companies of the media will establish a reasonable high-level management team and formulate appropriate strategies to ensure the stable and healthy growth of media companies and achieve long-term profitability of the company. At the same time, whether the listed companies in the media industry in China can obtain a high degree of truth from the management disclosure report of the company through the relevance of corporate management cognition, strategy and the company. How does the listed company ensure the authenticity of the disclosed information? What needs to be explored is that in the future, it will promote various industries to better improve the management and cognition aspects of the listing report in order to reflect the real situation of the company's internal management health to promote better development in this field in China. It also hopes to be able to play a role in attracting investment and make a contribution to the more comprehensive and comprehensive research in this field.

\section{Literature Review}

\subsection{Definition of Management Cognition}

Walsh (1995) believes that so-called management cognition is a set of knowledge structures of strategic decision makers [1]. This set of knowledge structures is a set of relevant information (weick and Bougon, 1986) and is used by strategic decision makers. "Search and interpret information in the environment" is divided into three levels: individual level, team level, and organizational level [2]. Organizational level of management knowledge explores the mind, thought, etc. expressed by the organization as a whole. Walsh (1995) Call it organization "sharing schema" [1].

Tikkanen, Ellstrand \& Daily (2000) believe that management cognition not only embodies the cognitive structure of strategic decision makers, but also a cognitive process or cognitive model [3]. It consists of past knowledge expe- 
riences and exists in the minds of top managers. A psychological model in which this model affects senior managers' understanding of objective phenomena and actions that will be taken afterwards.

Based on the above narratives, management cognition is considered to be a variety of information obtained by top management when faced with changes in the external environment and changes in the company's advantages. This information is recognized by the senior management team of the company and will be analyzed based on these results. Information and the establishment of corporate strategies and response measures ultimately affect corporate performance.

\subsection{The Definition of Flexible Strategy}

The template is used to format your paper and style the text. All margins, column widths, line spaces, and text fonts are prescribed; please do not alter them. You may note peculiarities. For example, the head margin in this template measures proportionately more than is customary. This measurement and others are deliberate, using specifications that anticipate your paper as one part of the entire journals, and not as an independent document. Please do not revise any of the current designations.

EvanS (1982) is defined as a flexible strategy to help reposition the ability to change conditions, and flexibility is an indispensable feature of planning strategy structures and schemes [4]. Bahrami (1992) pointed out that flexible strategies are the ability to accelerate conscious changes, respond to unpredictable changes, and adjust predictable changes to bring about unpredictable results [5]. Btjekley, Btjekley, and Casson (1998) define a flexible strategy as the ability of a company to quickly and smoothly reconfigure resources in response to changes [6].

In summary, this paper believes that flexible strategy is a characteristic of corporate strategy, and has the ability to change in time according to changes in the environment. In addition, the corporate flexibility strategy also represents the ability of the company to have the flexibility of resource changes.

\subsection{Definition of Business Performance}

Khanna \& Rivkin (2001) pointed out that using ROA to measure the economic performance of a company can avoid the impact of tax policy on performance and is better than other measures [7]. China is an emerging market. From the standpoint of measuring economic stability, ROA is better than ROS or SG. For the convenience and simplicity of measurement, this paper uses a single measurement method to represent the business performance of the company.

$\mathrm{ROA}=$ annual net profit/total assets ${ }^{*} 100 \%$.

\subsection{Relationship between Management Cognition and Corporate Strategy}

Shang Hangbiao (2010) proved that the limited rationality of strategic decision-making in enterprises is concentrated in the limited rationality of strategic 
decision-makers' management cognition, and the limited rational cognition of strategic decision-makers' management cognition affects the strategic decision-making of enterprises [8]. The strategic decision-making of enterprises under the dynamic environment is influenced by the cognition of the corporate strategic decision makers. In 2014, he also proposed that the level of dynamic capabilities of enterprises stems from the characteristics of strategic decision makers' management cognition [9].

The cognitive complexity of strategic decision makers is conducive to the accumulation and improvement of dynamic capabilities of enterprises. Management cognition helps to improve the company's ability to perceive new opportunities and its ability to grasp new strategic opportunities.

In addition, the concentration of knowledge structure of management knowledge has a significant negative impact on the speed of strategic response of enterprises, indicating that the more centralized the knowledge structure of strategic decision makers is, the slower the strategic response to changes in the environment will be. The complexity of the knowledge structure of knowledge has a positive effect on the speed of strategic response of the company. This shows that the more complex the knowledge structure of strategic decision makers is, the faster the strategic response of the company will be.

Wu Yajun (2013) research shows that in the complex and dynamic environment of China's transformation and development, the cognitive models and values of business leaders play an important role in the development of enterprises [10]. Ren Zhengfei's management cognitive model and value factors have influenced Huawei's long-term performance significantly by rationalizing or innovating the effectiveness of Huawei's strategic development, sharing property or incentive system innovation, and "seeking truth from facts" management progress.

Weick K E. (1979) learned that when dealing with complex and volatile environments, due to cognitive limitations, managers' perceptions and responses to the environment are often conducted through their long-standing management knowledge [11]. Eisenhardt K M. (1989) also confirmed that managers quickly make strategic choices in a rapidly changing environment through their familiar affairs and phenomena [12]. MacKay R (2006) pointed out that the failure of strategic choices by corporate executives and the resulting path dependence are the main reasons for the decline of the entire industry [13]. In the face of an increasingly complex and ever-changing environment, the possibility of organizations making strategic choices is increasingly constrained by the level of individual decision-makers' cognitive ability.

Liu Zhijiang (2011) pointed out in the "Knowledge, Skills and Applications of Enterprise Strategic Management" that there are four key factors that affect the success or failure of a company's strategic transformation [14]. The primary factor in the strategic transformation is the replacement of top management personnel. The article pointed out that the removal of CEOs or other senior management personnel is conducive to promoting strategic transformation, be- 
cause the newly appointed senior managers bring new management awareness to the company.

Barr (1998) pointed out that strategic change is not only the change of organizational structure and process, but also the process of repositioning the organization in terms of cognition [15]. Gavettiand Levinthal (2000) pointed out that management cognition limits the scope of information search by strategic decision makers and the direction of information interpretation, and affects the enterprise's grasp of external opportunities [16]. Based on the study of Gavetti and Levinthal (2000), Lamberg and Tikkanen (2006) deeply explored the mechanism of managerial cognition on the evolution of enterprise capabilities, and considered that management cognition is a key factor in shaping the dynamic capabilities of enterprises and organizational evolution [16] [17].

Yang Defeng and Yang Jianhua (2012) analyzed the listing report [18]. The more administrators think that environmental issues are the opportunities for enterprises to create competitive advantages and the stronger their awareness of environmental protection, the more likely they are to implement forward-looking environmental strategies. Know the impact on corporate strategy.

\subsection{The Impact of Management Cognition on Business Performance}

Xie Dewen and Lin Le (2015) used the text analysis often used in the computer field to analyze the tone of the management of listed companies from 2005 to 2012 in the tone of management and found that the net positive tone of the management and company $\mathrm{T}+1$ The annual performance was significantly positively correlated, and the positive (negative) tone of management was positively (negatively) related to the company's $T+1$ year performance [19]. These results show that after controlling for factors such as the company's performance in the $\mathrm{T}$ year, the management tone of the performance briefing can still provide incremental information on the company's future performance, indicating that the management tone of our listed company's annual performance description meeting is better The credibility.

Li Fengsen and Li Changqing (2008) recognized that the management discussion and analysis are indeed the most effective part of the company's performance predictions in the annual reports disclosed by listed companies. However, due to market supervision issues, listed companies may experience "good news but no reports" and affect investment. The analysis of company performance [20]. Chen Xiaoyue and Xu Xiaodong (2001) Empirical studies on the relationship between equity structure and corporate performance of listed companies outside the financial industry during the period 1996-1999 of the Shenzhen Stock Exchange show that management cognition affects the optimization of corporate governance and the improvement of corporate performance [21].

Xue Shuang (2010) selects the management discussion and analysis part of the loss-making company's listed annual report and the business plan information of the next year. Through software analysis, it is found that it can predict the 
performance of the company in the next year [22]. Lin Yaqing (2014) considers the important factor of strategic flexibility to better explain the mechanism of institutional support for corporate performance, which provides an important reference for institutional theories in obtaining the development and application of corporate competitive advantage [23].

Davis AK, Piger JM (2006) proposed that positive and negative pessimistic language words used in company-related press releases reflect the positive (negative) correlation and effects of the company's future performance [24]. The results indicate that managers provide in optimistic and pessimistic language. Relevant information regarding the expected future company performance to the market, and responding to the language usage of the market manager. Wang Tie-men and Chen Tao (2010) showed that different types of strategic flexibility (flexibility of resources and flexibility) have different effects on corporate performance, thus providing a theoretical basis and an effective approach for enterprises to improve their business performance [25].

Liu Jiasong and Wang Huifang (2006) used data to illustrate that there are still significant obstacles in the discussion and analysis of China's management [26]. The market should refine the information disclosure guidelines and strengthen supervision, and should also actively promote the disclosure environment such as the regulation of competitive markets and corporate governance mechanisms. The construction, thus motivating the company to increase management discussion and analysis of some of the information disclosure level.

\subsection{The Current Literature Gap in the Literature Review Section}

This chapter summarizes the definitions of management cognition, flexibility strategy and enterprise performance through the existing literature, and collates the relationship between management cognition and enterprise strategy, the impact of management cognition on enterprise performance, etc. In the literature, there is not a very theoretical and complete system for assessing corporate flexible strategies and corporate performance. There are not many empirical studies on management cognition and corporate performance, flexible strategies, and corporate performance in domestic and international literature. More is a theoretical study. However, these related documents provide relevant ideas for the following empirical analysis, and also have a clearer understanding of the theme of this paper.

\section{Research Models and Methods}

\subsection{Research Hypothesis}

This dissertation divides the concentration of executive management cognition into three parts: macro variables, industry competitive advantages, and enterprise integration capabilities.

The macro environmental variables refer to the general external environment that influences the top management team of enterprises to make various choices, 
mainly including political and legal factors (the laws or political systems issued by the state, with mandatory features), and the economic environment (global economy). Situation, the impact of globalization on the company's economy, and technological change (Internet technology innovation, the state encourages the use of technology transformation).

Enterprises often obtain the key factors of the macro environment and predict their changing trends through primary or secondary data. The number of different key factors collected mainly comes from the attention of the enterprise management, and finally makes relevant decisions. We make the following assumptions:

H1a: When the management concentration of the management of the senior management team of a listed company in the media is concentrated in the macro environment, the business performance of the company declines.

Huff (1992) mentioned that listed companies would attribute the poor operating performance of the company to environmental changes [27]. Because of the fixed nature of the industry's selection, the macro environmental changes faced by media listed companies over the past few years are the implementation of the Internet+, which exposes the traditional media business operations to more risks, and more media listings are facing the transition to new media and industries. upgrade. At this time, too much emphasis in the management discussion and analysis on the macroeconomic impact on the decline in business performance, we believe that this is an act attributed to external factors.

Industry competitive advantage refers to the advantages of resources and capabilities that an enterprise does not have or is difficult to imitate other competitors in the same industry. At the same time, when the enterprise environment changes rapidly, the enterprise has sufficient resources and can quickly adapt to the current environment. The ability is usually reflected in the company's ability to innovate and unique technologies. We make the following assumptions:

H1b: When the management concentration of the management of the senior management team of a listed company in the media is mostly used for industrial competitive advantage, the operating performance of the company increases.

The industry's competitive advantage of the enterprise is usually the response of the company's core expertise. The company has the ability to use its resources to continuously exert its core capabilities. Therefore, we believe that when the high-level management focuses more on the industry's competitive advantage, the company's operating performance increases.

The ability of enterprise integration not only refers to the ability of the enterprise to manage the enterprise to make it more efficient, but also refers to the effective use of external resources by the enterprise. It includes the integration of suppliers, customers and other companies that do not belong to the enterprise but belong to the upstream and downstream of the enterprise. After understanding its definition we can make the following assumptions:

H1c: When the management concentration of the senior management team of 
the listed company's management team focuses on the enterprise's ability to integrate, the business performance of the company increases.

Because most of the macro-environment changes are not very large, and when the executive team's attention is too focused on the macro-environment, the previous Huff (1992) mentioned that listed companies will attribute the poor operating performance of the company to In environmental changes [27], we believe that when business performance is not very good, senior executives are less concerned about corporate strategy flexibility, and corporate strategies often do not make significant changes. Therefore:

H2a: The relationship between the management concentration of the senior management of the media listed company and the change of the company's focus on the macro environment is in the opposite direction.

$\mathrm{H} 2 \mathrm{~b}$ : The relationship between the degree of concentration of the senior managerial management of the listed companies on the macro-environment and the flexibility of the company's response is in the opposite direction.

$\mathrm{H} 2 \mathrm{c}$ : The perception of the senior management of the media listed companies on the macro-environment and the flexibility of the company's resources are in a reverse relationship.

When enterprises focus on innovation and enhance their core competitiveness, strategies often need to have certain flexibility to adapt to technological innovation, and put forward various innovation strategies. And Nelson (1982) proposed that when companies focus on the competitive advantage of the industry, they often make changes in their strategic diversification [28]. Therefore, the company's strategy will also be more flexible.

Because we make the following assumptions:

H2d: The relationship between the concentration of attention of the executives of the listed companies in the management of the media to the industry's competitive advantage and the positive changes in the flexibility of the enterprise's transformation;

H2e: The relationship between the degree of concentration of attention of the executives of the listed companies in the management of the media and the flexibility of the corporate response to positive changes in the corporate response;

H2f: The high level management awareness of media listed companies has a positive relationship between the degree of concentration of attention to the industry's competitive advantage and the flexibility of the company's resources.

When companies can better integrate internal and external resources and advantages, we believe that companies can make reasonable use of internal and external resources owned by the company. In general, when the enterprise's ability to integrate is stronger, the company's strategy is often more flexible. Therefore, we make the following assumptions:

$\mathrm{H} 2 \mathrm{~g}$ : The relationship between the degree of concentration of executive management cognition on the ability of corporate integration and the positive change in the flexibility of corporate change in the media listed companies;

$\mathrm{H} 2 \mathrm{~h}$ : The relationship between the degree of concentration of executive man- 
agement cognition on the ability of corporate integration and the flexibility of corporate response is positive.

H2i: The high level of management awareness of media listed companies has a positive relationship between the degree of concentration of corporate integration capabilities and the flexibility of corporate resources.

Flexible strategy usually indicates the degree of change of corporate strategy. There are various assumptions about the relationship between corporate strategy and corporate performance. Because there is not much empirical research on the relationship between flexible strategy and corporate performance, most of them are still Based on theoretical research, most data in empirical research have measured the positive relationship between flexible strategies and corporate performance. For example, Xie Weihong (2010) proved that the positive impact of corporate strategic flexibility on corporate performance is clear. At the same time, the purpose of the strategy flexibility is often to enable the company to have better business performance [29]. Therefore, this paper assumes:

H3a: The relationship between the flexible strategy of the listed companies and the positive changes in corporate performance;

H3b: Media listed companies respond to positive changes in the relationship between flexible strategies and corporate performance;

$\mathrm{H} 3 \mathrm{c}$ : The relationship between the flexible strategy of the listed company's resources and the positive performance of corporate performance;

\subsection{Sampling Methods for Various Variable Data}

First, we have selected 21 companies listed on the media to have complete annual reports during the 2012-2016 five-year period, so a total of 105 data will be used.

Second, Levy (2005) used the company's annual report and financial statements to analyze the degree of management awareness of senior management [30]. He mainly divided the corporate environment into two parts, internal and external, and used text analysis to analyze internal and external keywords. Therefore, this paper also divides the management cognition into three parts with the key words: macro environment, industry competitive advantage and enterprise integration ability.

Thirdly, NVivo's qualitative analysis software was used to measure the annual report of the Board of Directors to discuss and analyze the word frequencies of some of the three major categories of vocabularies. When a word related to the above keywords appears in a sentence, the sentence is classified into this category and marked with Nvivo, and finally it is taken as a percentage of the entire management discussion and analysis. In this way, you can turn these textualized content into data-based content, and perform correlation analysis and regression analysis in SPSS software.

There are many different kinds of flexible strategies and many methods are obtained. Most of them are obtained through questionnaires. This paper studies listed companies and does not have the advantage of in-depth interviews. 
Therefore, we decided to choose indicators that can be measured in annual reports of listed companies. Finally, the following three indicators were selected in a comprehensive manner, just like the Table 1 showing:

A. Leiponen (1997) used employee average education as a measure of enterprise resource flexibility in the study, and confirmed that the higher the employee's average levels of education, the better the resource flexibility of the enterprise [31]. Li Wei (2006) adopted the sales profit rate as the flexibility of the company, and the current ratio as the flexible measure of the company's response. It is proved that the better the company's sales profit rate, the better the company's changeability flexibility; the higher the company's liquidity ratio, the better the response flexibility. The above conclusions prove that it is feasible to use these three variables as variables of the company's flexible strategy, and for listed companies, it is relatively easy to find corresponding data in listed companies and perform calculations using such measurement methods. In addition, for media companies, the flexible manpower strategy is an important capital.

The listed company data used in this paper are all media industry. In order to improve the accuracy of the model, the following three control variables are selected:

Enterprise size: The scale of an enterprise is generally measured by three indicators: the first is the total number of employees in the enterprise, the second is the total assets of the enterprise, and the third is the sales revenue of the enterprise. Zhang Min (2008) believes that when measuring the size of a company, it is appropriate to measure the size of the company by the number of its total assets [32]. In general, directly measuring the total assets of a company will result in a large number of unsuitable ones. Therefore, in the empirical analysis of management and finance, in order to avoid that the variables do not obey the normal distribution, and generally do not change the nature of the probabilities, usually Measure the total number of assets taken as a logarithm.

Enterprise age: The age at which the company selects the analysis data from registration to this paper. Because the age of the company affects the implementation of the company's flexible strategy, it is used as a control variable.

Asset-liability ratio (corporate total liabilities/total corporate assets): In a number of management-related studies, asset-liability ratios are used as control variables.

Table 1. Flexible strategy measurement indicator selection and description.

\begin{tabular}{ccc}
\hline Strategic flexibility type & measurement standard & definition \\
\hline Change flexibility strategy & Total profit/net sales \\
Reactive flexibility strategy & Current ratio & Current assets/current liabilities \\
Resource flexibility strategy & $\begin{array}{c}\text { Average educational } \\
\text { level of employees }\end{array}$ & $\begin{array}{c}\text { below }+3 \times \text { the number of } \\
\text { undergraduates }+5 \times \text { the number } \\
\text { of graduate students and above }) / \\
\text { Total number of employees }\end{array}$ \\
\hline
\end{tabular}




\section{Empirical Results and Analysis}

\subsection{Authors and Affiliations}

As of April 2018, in the media industry, China has a total of 54 listed companies in the media. After screening, ST and $\mathrm{ST}^{*}$ companies were removed. They chose to have annual listings in 2012-2016 and remained in this fiscal year in 2017. Normally listed media companies, so there are a total of 21 qualified media listed companies.

The financial data of this paper comes from China Finance Network (http://finance.china.com.cn/) and the listed company's annual report comes from CNINFO (http://www.cninfo.com.cn/cninfo-new/index). Resource flexibility is formed by manual calculation and entry.

This paper mainly uses the qualitative software Nvivo10 for text analysis, and uses EXCEL2013 and SPSS 22.0 and other software for descriptive statistical analysis of variables, correlation analysis and regression analysis.

\subsection{Descriptive Statistics of Each Variable}

The data is analyzed by spss processing. Table 2 shows the descriptive statistics of relevant variables of the listed companies in the media.

\subsection{Correlation Analysis}

From the Table 3 list of correlations of variable coefficients, the relationship between macro-environment and flexible strategies and corporate performance can be reversed; industry competitive advantages and flexible strategies and corporate performance are positively correlated; corporate integration capabilities and flexible strategies and corporate performance are positive. The relationship between changes; changes in flexible strategies and corporate performance are positively correlated; responsive flexible strategies and corporate performance are positively correlated; and resource flexible strategies and corporate performance are positively correlated.

Table 2. Descriptive statistics of relevant variables of listed companies in the media.

\begin{tabular}{ccccc}
\hline Variable code & Min & MAX & Mean & Standard deviation \\
\hline Macro environment & $0.00 \%$ & $5.38 \%$ & $2.0347 \%$ & $1.23993 \%$ \\
Industry Competitive Advantage & $0.98 \%$ & $0.98 \%$ & $4.1785 \%$ & $1.69864 \%$ \\
Corporate integration capabilities & $0.75 \%$ & $6.68 \%$ & $3.4698 \%$ & $1.37287 \%$ \\
ol & -20.4464 & 38.2040 & 13.236351 & $8.8193633 \mathrm{z}$ \\
Current ratio & 0.2163 & 51.0677 & 3.419734 & 5.2575620 \\
Average educational & & & & 0.52041 \\
level of employees & 1.16 & 2.99 & 1.9318 & 3.9454045 \\
Business performance (ROA) & -9.3355 & 15.5031 & 6.835113 & \\
\hline
\end{tabular}

From spss software. 
Table 3. List of coefficients of listed companies in media companies.

\begin{tabular}{|c|c|c|c|c|c|c|c|}
\hline & variable & 1 & 2 & 3 & 4 & 5 & 6 \\
\hline 1 & Macro environment & 1 & & & & & \\
\hline 2 & $\begin{array}{l}\text { Industry Competitive Ad- } \\
\text { vantage }\end{array}$ & $-0.858^{* *}$ & 1 & & & & \\
\hline 3 & $\begin{array}{c}\text { Corporate integration ca- } \\
\text { pabilities }\end{array}$ & $-0.874^{\star *}$ & $0.966^{* *}$ & 1 & & & \\
\hline 4 & ol & $-0.599^{\star *}$ & $0.700^{* *}$ & $0.715^{\star *}$ & 1 & & \\
\hline 5 & Current ratio & $-0.200^{*}$ & $0.253^{* *}$ & $0.220^{*}$ & $0.309^{* *}$ & 1 & \\
\hline 6 & $\begin{array}{l}\text { Average educational } \\
\text { level of employees }\end{array}$ & -0.183 & 0.169 & $0.193^{*}$ & 0.104 & $0.768^{\star *}$ & \\
\hline 6 & ROA & $-0.833^{\star *}$ & $0.931^{\star *}$ & $0.955^{\star *}$ & $0.768^{* *}$ & $0.245^{\star}$ & 1 \\
\hline
\end{tabular}

From spss software.

\section{Analysis and Inspiration of Empirical Results}

\subsection{Summary of Empirical Results}

The purpose of this paper is to reveal the internal relationship among the management cognition, flexible strategy and corporate performance of the top management team of the listed company of the media, and to illustrate the importance of management discussion and analysis in the annual report, and to inspire the companies of the media listed companies. We pay attention to management team management awareness, so that corporate performance can be improved. The previous chapter of this chapter validated the assumptions made in the paper through correlation analysis and regression analysis. The results obtained are shown in Table 4.

First, the executive management cognition and corporate performance of the listed companies in the media: The relationship among the three variables proposed by the executive management cognition and the corporate performance are supported;

Second, the management awareness of media listed companies is focused on the macro environment, which has a negative impact on the enterprise's flexibility of change and resource flexibility. Management's cognitive focus is on the industry's competitive advantage, and it is positive on the enterprise's flexibility of change and resource flexibility. Impacts: Management's cognitive focus is on enterprise integration capabilities, which has a positive impact on organizational flexibility and resource flexibility.

Third, the media listed companies' flexible strategies and corporate performance. The listed companies in the media have a positive relationship among change flexibility, resource flexibility, and corporate performance.

\subsection{Limitations of Research}

First, when analyzing high-level managerial cognition and flexible strategy, this paper adopts the content and data in the annual report of the board of directors. 
Table 4. Research hypotheses empirical analysis results.

\begin{tabular}{|c|c|c|c|}
\hline & $\begin{array}{l}\text { Hypothesis } \\
\text { Number }\end{array}$ & Research hypothesis & test result \\
\hline 1 & H1a & $\begin{array}{l}\text { When the concentration of managerial cognition in the } \\
\text { management of the listed company's senior management team } \\
\text { focused on the macro environment, the business } \\
\text { performance of the company declined. }\end{array}$ & Get support \\
\hline 2 & $\mathrm{H} 1 \mathrm{~b}$ & $\begin{array}{l}\text { When the concentration of management awareness of the } \\
\text { senior management team of a listed company in the media } \\
\text { focuses on the industry's competitive advantage, } \\
\text { the company's operating performance increases. }\end{array}$ & Get support \\
\hline 3 & $\mathrm{H} 1 \mathrm{c}$ & $\begin{array}{l}\text { When the concentration of management awareness of the } \\
\text { senior management team of a listed company in the media } \\
\text { focuses on the enterprise's ability to integrate, the company's } \\
\text { operating performance will increase. }\end{array}$ & Get support \\
\hline 4 & $\mathrm{H} 2 \mathrm{a}$ & $\begin{array}{l}\text { The relationship between the degree of concentration of } \\
\text { attention of the executives of the listed companies in the } \\
\text { management of the media and the change in the flexibility } \\
\text { of the company is in the opposite direction. }\end{array}$ & Get support \\
\hline 5 & $\mathrm{H} 2 \mathrm{~b}$ & $\begin{array}{l}\text { The degree of concentration of attention on the } \\
\text { macro-environment in the management of public companies } \\
\text { listed in the media and the flexibility of the company's } \\
\text { response are in a reversed relationship. }\end{array}$ & $\begin{array}{c}\text { Not } \\
\text { supported }\end{array}$ \\
\hline 6 & $\mathrm{H} 2 \mathrm{c}$ & $\begin{array}{l}\text { The degree of concentration of attention on the } \\
\text { macro-environment of the senior management of the listed } \\
\text { companies in the media has changed in a reverse relationship } \\
\text { with the flexibility of the company's resources. }\end{array}$ & Get support \\
\hline 7 & $\mathrm{H} 2 \mathrm{~d}$ & $\begin{array}{l}\text { The degree of concentration of attention of the executives } \\
\text { of the listed companies in the management of the media } \\
\text { to the industry's competitive advantage is positively } \\
\text { related to the flexibility of the enterprise's change. }\end{array}$ & Get support \\
\hline 8 & $\mathrm{H} 2 \mathrm{e}$ & $\begin{array}{l}\text { The relationship between the degree of concentration of } \\
\text { attention on the industry's competitive advantage and the } \\
\text { positive change in the flexibility of the corporate response } \\
\text { to the perceptions of executives of media listed } \\
\text { companies' senior management }\end{array}$ & $\begin{array}{c}\text { Not } \\
\text { supported }\end{array}$ \\
\hline 9 & $\mathrm{H} 2 \mathrm{f}$ & $\begin{array}{l}\text { The high level of management awareness of media listed } \\
\text { companies has a positive relationship between the degree of } \\
\text { concentration of industry's competitive advantage } \\
\text { and the flexibility of the company's resources. }\end{array}$ & Get support \\
\hline 10 & $\mathrm{H} 2 \mathrm{~g}$ & $\begin{array}{l}\text { There is a positive relationship between the degree of } \\
\text { concentration of attention on corporate integration capabilities } \\
\text { and the flexibility of corporate innovation in the } \\
\text { management of public companies listed on the media. }\end{array}$ & Get support \\
\hline 11 & $\mathrm{H} 2 \mathrm{~h}$ & $\begin{array}{l}\text { There is a positive relationship between the degree of } \\
\text { concentration of attention of the executives of the listed } \\
\text { companies in the management of the media and the } \\
\text { flexibility of the corporate response. }\end{array}$ & $\begin{array}{c}\text { Not } \\
\text { supported }\end{array}$ \\
\hline
\end{tabular}




\section{Continued}

\begin{tabular}{llll}
\hline 12 & H2i $\quad \begin{array}{l}\text { The degree of concentration of attention of the executives } \\
\text { of the listed companies in the management of the media } \\
\text { to the company's ability to integrate has a positive } \\
\text { relationship with the flexibility of corporate resources. }\end{array}$ \\
$13 \quad$ H3a $\quad \begin{array}{l}\text { There is a positive relationship between the flexibility of the } \\
\text { listed company's reform strategy and corporate performance. }\end{array}$ & Get support \\
14 & H3b $\quad \begin{array}{l}\text { The listed companies in the media responded positively to } \\
\text { changes in flexible strategies and corporate performance. } \\
15\end{array} \quad$ H3c $\quad \begin{array}{l}\text { There is a positive relationship between the flexible strategies } \\
\text { of resource listed companies and corporate performance. }\end{array}$ & Get support \\
\hline
\end{tabular}

Both are secondary data. Due to limitations, they cannot directly obtain more data from the enterprise. Try to adopt a questionnaire interview mode for enterprises to obtain more accurate data sources.

The second is the limitation of the research method. The corporate environment is not always in a static environment. This paper ignores the influence of the dynamic environment of the enterprise, and the flexible strategy has a certain lag, and the paper pays less attention to it.

\section{References}

[1] Walsh, J.R. (1995) Managerial and Organizational Cognition: Notes from a Trip Down Money Lane. Organization Science, No. 3, 280-321. https://doi.org/10.1287/orsc.6.3.280

[2] Weick, K.E. and Bougon, M.G. (1986) Organizations as Cognitive Maps: Charting Ways to Success and Failure. The Thinking Organization, 102-135.

[3] Tikkanen, L., Ellstrand, A.E., Daily, C.M., et al. (2000) Composition of the Top Management Teamand Firm International Diversification. Journal of Management, 26, 1157-1177. https://doi.org/10.1177/014920630002600605

[4] Hochmuth, R.M., Wiles, H.C., Evans, E.A., et al. (1982) Extensional Flow of Erythrocyte Membrane from Cell Body to Elastic Tether. II. Experiment. Biophysical Journal, 39, 83. https://doi.org/10.1016/S0006-3495(82)84493-7

[5] Bahrami, H. (1992) The Emerging Flexible Organization: Perspectives from Silicon Valley. California Management Review, 34, 33-52. https://doi.org/10.2307/41166702

[6] Buckley, P.J. and Casson, M.C. (1998) Analyzing Foreign Market Entry Strategies: Extending the Internalization Approach. Journal of International Business Studies, 29, 539-561. https://doi.org/10.1057/palgrave.jibs.8490006

[7] Khanna, T. and Rivkin, J.W. (2001) Estimating the Performance Effects of Business Groups in Emerging Markets. Strategic Management Jourual, 22, 45-74. https://doi.org/10.1002/1097-0266(200101)22:1<45::AID-SMJ147>3.0.CO;2-F

[8] Shang, H.B. (2010) Research on the Impact of Strategic Decision Makers' Management Cognition on Strategic Response Speed and Dynamic Capabilities under Dynamic Environment. South China University of Technology, Guangzhou.

[9] Shang, H.B., Tian, G.S. and Huang, P.L. (2014) Research on the Influence Mechanism of Management Cognitive Features on Dynamic Capability. Journal of East China Economic Management, 28, 79-84.

[10] Wu, Y.J. (2013) "Strategic Framework Thinking", "Integration of Public Opinions" 
and Corporate Competitive Advantage: Ren Zhengfei's Cognitive Model Analysis and Management Inspiration. Management World, No. 4, 150-167.

[11] Webb, E. and Weick, K.E. (1979) Unobtrusive Measures in Organizational Theory: A Reminder. Administrative Science Quarterly, 24, 650-659. https://doi.org/10.2307/2392370

[12] Eisenhardt, K.M. (1989) Making Fast Strategic Decisions in High-Velocity Environments. Academy of Management Journal, 32, 543-576.

[13] MacKay, R., Masrani, S. and McKiernan, P. (2006) Strategy Options and Cognitive Freezing: The Case of the Dundee Jute Industry in Scotland. Futures, 38, 925-941. https://doi.org/10.1016/j.futures.2005.12.014

[14] Liu, Z.J. (2011) Management Principles and Applications. Harbin Institute of Technology Press, Harbin, 509.

[15] Barr, P.S. (1991) Adapting Resources and Sustainable Competitive Advantage. Journal of Management, 17, 99-120. https://doi.org/10.1177/014920639101700108

[16] Lamberg, J.A. and Tikkanen, H. (2006) Changing Sources of Competitive Advantage: Cognition and Path Dependence in the Finnish Retail Industry 1945-1995. Industrial and Corporate Change, 15, 811-846. https://doi.org/10.1093/icc/dtl018

[17] Gavetti, G. and Levinthal, D. (2000) Looking Forward and Looking Backward: Cognitive and Experiential Search. Administrative Science Quarterly, 45, 113-137. https://doi.org/10.2307/2666981

[18] Yang, D., Yang, J., Lou, R., et al. (2012) Impact of Stakeholders, Management Cognition on the Choice of Corporate Environmental Protection Strategy: An Empirical Study Based on Listed Companies in China. Management Review, 24, 140-149.

[19] Xie, D. and Lin, L. (2015) Can Management Tone Predict the Future Performance of the Company?-A Text Analysis Based on the Annual Performance of Listed Companies in China. Accounting Research, No. 2, 20-27.

[20] Li, F. and Li, C. (2008) A Study on the Usefulness of "Management Discussion and Analysis" of Listed Companies. Securities Market Herald, 12, 67-73.

[21] Chen, X. and Xu, X. (2001) Ownership Structure, Corporate Performance and Investor Interest Protection. Economic Research, 11, 11.

[22] Xue, S., Xiao, Z. and Pan, X. (2010) Does the Management Discussion and Analysis Provide Useful Information?-Based on the Empirical Exploration of Loss-Making Listed Companies. Management World, No. 5, 130-140.

[23] Lin, Y. and Zhao, Y. (2014) Research on the Relationship between Institutional Support and Corporate Performance Based on the Influence of Strategic Flexibility and Technological Capabilities. Chinese Journal of Management, 11, 46-54.

[24] Davis, A.K., Piger, J.M. and Sedor, L.M. (2006) Beyond the Numbers: An Analysis of Optimistic and Pessimistic Language in Earnings Press Releases. Federal Reserve Bank of St. Louis Working Paper Series (2006-005).

[25] Wang, T., Chen, T. and Jia, Y. (2010) Empirical Study on the Effect of Organizational Learning and Strategic Flexibility on Firm Performance. Journal of Management Science, 13, 42-59.

[26] Liu, J. and Wang, H. (2006) Influencing Factors of Company's Management Discussion and Analysis of Information Disclosure-Based on the Empirical Evidence of 223 Listed Companies in Shenzhen and Shanghai. Journal of Chongqing Technology and Business University: Western Forum, 16, 73-76.

[27] Barr, P., Stimpert, L. and Huff, A. (1992) Cognitive Change, Strategic Action, and Organizational Renewal. Strategic Management Journal, 15-36. 
[28] Nelson, W. (1982) An Evolutionary Theory of Economic Change. Harvard University Press, Cambrige.

[29] Xie, W., Zhang, Z., Zhu, G. and Zhang, Z. (2007) An Empirical Study on the Relationship between Firm Flexibility and Corporate Performance from the Perspective of Organizational Frontier: Taking the Manufacturing Industry in the Pearl River Delta as an Example. Reform and Strategy, No. 7, 28-31.

[30] Levy, O. (2005) The Influence of Top Management Team Attention Patterns on Global Strategic Posture of Firms. Journal of Organizational Behavior, 26, 797-819. https://doi.org/10.1002/job.340

[31] Leiponen, A. (1997) Dynamic Competences and Firm Performance. IIASA.

[32] Yang, L. and Zhang, M. (2008) A Review of Research on the Theory and Experience of Foreign Companies' Strategic Transformation. Foreign Economics and Management, No. 5, 56-65. 